\title{
Expanding management and leadership education in medical schools
}

\author{
Aqib Chaudry \\ Amar Sodha \\ Ahmed Nur \\ Faculty of Medicine, Imperial College \\ London, London, UK
}

This article was published in the following Dove Press journal:

Advances in Medical Education and Practice

\section{Dear editor}

We read with great interest the article by Rouhani et $\mathrm{al}^{1}$ exploring the perceptions, attitudes, and interest of UK medical students toward medical leadership. As medical students who recently completed an intercalated degree in health care management at Imperial College London, we can offer a unique perspective on this important issue.

We first commend the authors for this multi-institutional study identifying current perceptions and attitudes of medical students toward "Clinician Managers" and the level of management and leadership training they have received. Rouhani et a ${ }^{1}$ identified a significant gap between the demand for management and leadership training and that provided by UK medical schools. This was highlighted by the findings that $63 \%$ of students would have liked more management or leadership training and more than half of respondents rated their training as "very poor" or "poor." These findings exist despite the Medical Leadership Competency Framework defining core management and leadership skills required by health professionals.

Furthermore, we also see the benefits of introducing a formal leadership course within the curriculum as argued by Rouhani et al. ${ }^{1}$ However, further research must be undertaken to identify, first, the optimal stage in medical school for the course to be delivered and, second, how the course can be integrated within the current curriculum.

Abbas et $\mathrm{al}^{2}$ identified a lack of time available in the curriculum as a key barrier to the introduction of more extensive leadership training. Thus, in order to facilitate the significant demand, we suggest two solutions that do not affect curriculum time while broadening the opportunities available to students.

First, from our own experiences and preexisting literature, students should be given greater opportunity to intercalate at institutions offering health care management BSc courses. These programs contain modules that cover the five domains outlined in the Medical Leadership Competency Framework: demonstrating personal qualities, working with others, managing services, improving services, and setting direction. ${ }^{1}$ In addition, students are able to appreciate the complexity of financial decisions in the health care environment by understanding health economic principles. ${ }^{3}$ Singh et $\mathrm{al}^{4}$ even proposed the idea of a mandatory health care management BSc.

While it may not be feasible for some institutions to offer such intercalated programs, an easier-to-implement solution to cater for the growing demand for leadership training is the introduction of a Medical Leadership Society at medical schools. 
Thus, students demonstrating particular interest can attend workshops, conferences, team-building exercises, and guestspeaker talks held by the society outside curriculum hours. These societies can use frameworks outlined by the NHS Leadership Academy to guide their events. ${ }^{5}$ Given the desire from students for such opportunities, and that only $7.9 \%$ of students felt informed about what a managerial role in medicine included, ${ }^{1}$ the introduction of such a society will likely be welcomed by students.

However, in order to ascertain whether these changes will improve leadership training in medical schools, we believe further research is required comparing perceptions in leadership training between students with exposure to Medical Leadership Societies and Health Management degrees with those exposed solely to the undergraduate medical curricula.

\section{Disclosure}

The authors report no conflicts of interest in this communication.

\section{References}

1. Rouhani M, Burleigh E, Hobbis C, et al. UK medical students; perceptions, attitudes, and interest toward medical leadership and clinician managers. Adv Med Educ Pract. 2018;9:119-124.

2. Abbas MR, Quince TA, Wood DF, Benson JA. Attitudes of medical students to medical leadership and management: a systematic review to inform curriculum development. BMC Med Educ. 2011;11(1):93.

3. Ashraf A, Sherwani Y, Najim M, et al. Should basic health economics principles be taught during medical school in the UK? Med Educ Online. 2015;20:29541.

4. Singh B, Shah N, Singagireson S, Ramjeeawon N. Should an iBSc in Management be compulsory for all UK medical students? Adv Med Educ Pract. 2015;6:383-384.

5. Sherwani Y, Ahmed A, Ahmed M, et al. Addressing the need and void of leadership and management development among medical students in the UK. Adv Med Educ Pract. 2015;6:579-580. 


\section{Authors' response}

Maral J Rouhani'

Eleanor J Burleigh ${ }^{2}$

Chloe Hobbis ${ }^{2}$

Charlotte Dunford'

Nadir I Osman ${ }^{3}$

Christine Gan'

Norma B Gibbons'

Hashim U Ahmed ${ }^{1,4}$

Saiful Miah ${ }^{1,5}$

'Department of Urology, Imperial College Healthcare NHS Trust, Charing Cross Hospital, London, UK; ${ }^{2}$ Medical School, University of Sheffield, Sheffield, UK; ${ }^{3}$ Department of Urology, Royal Hallamshire Hospital, Sheffield, UK; ${ }^{4}$ Division of Surgery, Department of Surgery and Cancer, Imperial College London, London, UK; ${ }^{5}$ Division of Surgery and Interventional Science, University College London, London, UK

Correspondence: Saiful Miah

Division of Surgery and Interventional Science, University College London, 2 I University Street, London WCIE 6AU, UK

Email saiful.miah@ucl.ac.uk

\section{Dear editor}

We read with great interest the response to our article ${ }^{1}$ by Chaudry et al. Their group have contemporary insight and valuable experience in this subject which can be attributed to the intercalated degrees they have undertaken in health care management. We are acutely aware that very few UK medical schools actually offer such an intercalated degree. However, we believe the proposal of Singh et al $^{2}$ of a compulsory health care management $\mathrm{BSc}$ is a counterproductive one. Basic science and clinically orientated intercalated degrees expose the medical student to research techniques and methodology. At their very core, they inspire the medical mind and are not designed to instruct all doctors to be academic research scientists, but rather ensure that every clinician's mind is tuned to continually evaluate standard practice, and ask can we do better? In principle, they are one of the driving forces behind innovation and continued professional development which are imperative to best practice in professional life. There are of course individuals who go on to pursue careers in research which is a fantastic secondary outcome, but in the same way that UK workforce planning doesn't require that all doctors are academic research scientists, it does not require that all doctors are managers. Currently, there is a lack of understanding of management and leadership among clinicians and we have demonstrated this is felt at the grass roots level in medical schools.

We welcome and encourage Chaudry et al suggestion of creating Medical Leadership Societies at medical schools. This will allow excellent learning and networking opportunities especially when invited external speakers are provided a platform to showcase the importance of clinician managers and medical leadership. However, we would like to stress that this format of management and leadership teaching delivery should be an adjunct for the medical student with a keen interest. It should not be used as a substitute to what we feel must be offered in the undergraduate curricula. As urologists we understand all too well that the current undergraduate medical curricula is without doubt crowded, as many medical students will never be exposed to our speciality in their training. ${ }^{3}$ However as our study has highlighted, management and leadership disciplines are applicable in a pan-speciality manner to benefit the clinical outcomes for all patients and the UK medical workforce as a whole. ${ }^{1}$ The data from our study suggest that many students are not even aware of the fundamentals and nomenclature of health care management and leadership and this needs to be addressed urgently. ${ }^{1}$

Finally, we are in agreement with Chaudry et al regarding the call for more research into the topic of delivering and assessing health care management and leadership training to undergraduates. Similar pleas have been made previously with suggestions of assistance from professional bodies such as the General Medical Council to implement nationally agreed and evidence-based programs. ${ }^{4}$ We firmly believe that medical management and leadership should now be an undergraduate priority.

\section{Disclosure}

The authors report no conflicts of interest in this communication.

\section{References}

1. Rouhani MJ, Burleigh EJ, Hobbis C, et al. UK medical students' perceptions, attitudes, and interest toward medical leadership and clinician managers. Adv Med Educ Pract. 2018;9:119-124.

2. Singh B, Ramjeeawon N, Shah N, et al. Should an iBSc in Management be compulsory for all UK medical students? Adv Med Educ Pract. 2015;6:383-384.

3. Miah S, Mangera A, Venugopal S, et al. The clinical need for undergraduate urology. Clin Teach. 2015;12(5):353-355.

4. Ah-Kee EY, Khan AA. Incorporating medical leadership and management into the UK undergraduate medical curriculum. Adv Med Educ Pract. 2015;6:507-508. 
Dove Medical Press encourages responsible, free and frank academic debate. The content of the Advances in Medical Education and Practice 'letters to the editor' section does not necessarily represent the views of Dove Medical Press, its officers, agents, employees, related entities or the Advances in Medical Education and Practice editors. While all reasonable steps have been taken to confirm the content of each letter, Dove Medical Press accepts no liability in respect of the content of any letter, nor is it responsible for the content and accuracy of any letter to the editor.

Advances in Medical Education and Practice

Dovepress

\section{Publish your work in this journal}

Advances in Medical Education and Practice is an international, peerreviewed, open access journal that aims to present and publish research on Medical Education covering medical, dental, nursing and allied health care professional education. The journal covers undergraduate education, postgraduate training and continuing medical education including emerging trends and innovative models linking education, research, and health care services. The manuscript management system is completely online and includes a very quick and fair peer-review system. Visit http://www.dovepress.com/testimonials.php to read real quotes from published authors.

Submit your manuscript here: http://www.dovepress.com/advances-in-medical-education-and-practice-journal 